ScIDice

\section{Knowledge Attitude And Practice Of Dentists Towards Prophylaxis After Exposure To Blood And Body Fluids}

Research Article

Abhishek Naram ${ }^{1}$, Balakrishna.R.N²* Deepak.S ${ }^{3}$

${ }^{1}$ Saveetha Dental College and Hospitals, Saveetha Institute of Medical and Technical Sciences (SIMATS), Saveetha University, Chennai - 600 077, India. ${ }^{2}$ Senior Lecturer, Department of Oral and Maxillofacial Surgery, Saveetha Dental College and Hospitals, Saveetha Institute of Medical and Technical Sciences (SIMATS), Saveetha University, Chennai - 600 077, India.

${ }^{3}$ Senior Lecturer, Department of Conservative Dentistry and Endodontics, Saveetha Dental College and Hospitals, Saveetha Institute of Medical and Technical Sciences (SIMATS), Saveetha University, Chennai - 600 077, India.

\title{
Abstract
}

Post-exposure prophylaxis plays an important role in prevention of blood and borne diseases after occupational exposures. This study was aimed at assessing the level of knowledge, attitude and practice of dental students on prophylaxis after exposure to blood and body fluids. A self administered questionnaire consisting of 10 questions regarding knowledge attitude and practice regarding prophylaxis after exposure to blood and body fluids. Data was collected through google forms. responses were analysed and statistical data is represented as pie charts. In the present study $48 \%$ of the participants know the duration of PEP to be taken. $96 \%$ of the students agree to the fact that PEP reduces the likelihood of being HIV positive. $68 \%$ of the participants did not attend any training program regarding PEP. Knowledge, attitude and practice of dentists working in Saveetha dental college towards prophylaxis after exposure to blood and body fluids is adequate but there are knowledge gaps. Interventions to raise their knowledge are therefore recommended.

Keywords: Body Fluids; Dentist; Occupational Exposure; Post Exposure Prophylaxis.

\section{Introduction}

Occupational exposure is defined as contamination of a health care worker (HCW) with patient's blood or body fluids during his/her professional practice.These exposures, which are common among HCWs, include sharp injuries, mucocutaneous contamination, and bites. These exposures are an important hazard for HCWs because they can result in the transmission of bloodborne pathogens such as hepatitis B virus (HBV), hepatitis C virus (HCV), and human immunodeficiency virus (HIV) Although avoiding exposures is very important for preventing transmission of the pathogens, post-exposure prophylaxis (PEP) is also an essential element of programs to stop infection and is vital for HCWs' safety. [1]

PEP includes procedures that have to be done after exposure to patients' blood and body fluids to stop probable microorganism transmission.[1] These procedures include immediate washing of the exposed area; determination of risk associated with exposure; evaluation of the source patient for acquired immune deficiency syndrome (AIDS), HBV and HCV; injection of hepatitis B vaccine and immunoglobulin; consumption of antiretroviral drugs; and evaluation and follow from the exposed HCW. [2] Each of those procedures is indicated under a particular circumstance and a number of other studies have shown their efficacy. [3] The study of Cardo, et al, showed that consuming zidovudine after injury with a needle contaminated by HIV-positive patient's blood reduced the risk of HIV transmission by approximately $80 \%$. [3] After exposure to $\mathrm{HBs}-\mathrm{Ag}+$ blood, injecting either hepatitis B vaccine or immunoglobulin alone can reduce the risk of $\mathrm{HBV}$ infection by nearly $70 \%$, according to the Center for Disease Control and Prevention (CDC) guidelines. [1]

Dentists are more prone to occupational exposure because of close contact with the patients' oral cavity, using sharp instru-

\section{*Corresponding Author}

Balakrishna.R.N,

Senior Lecturer, Department of Oral and Maxillofacial Surgery, Saveetha Dental College and Hospitals, Saveetha Institute of Medical and Technical Sciences (SIMATS), Saveetha

University, Chennai - 600 077, India.

E-mail: balakrishnarn.sdc@saveetha.com

Received: May 08, 2021

Accepted: June 16, 2021

Published: June 25, 2021

Citation: Abhishek Naram, Balakrishna.R.N, Deepak.S. Knowledge Attitude And Practice Of Dentists Towards Prophylaxis After Exposure To Blood And Body Fluids. Int J Dentistry Oral Sci. 2021;8(6):2873-2878. doi: http://dx.doi.org/10.19070/2377-8075-21000583

Copyright: Balakrishna.R.N ${ }^{\circ}$ 2021. This is an open-access article distributed under the terms of the Creative Commons Attribution License, which permits unrestricted use, distribution and reproduction in any medium, provided the original author and source are credited. 
ments and operating with high speed rotary instruments, which produce infectious aerosols. [4, 5] According to a previous study, $73 \%$ of dental students at Shiraz University of Medical Sciences had been injured with a sharp instrument a minimum of once during their clinical practice.[6] In London, only $76 \%$ of junior doctors were aware that PEP would reduce HIV transmission. [7] In Scotland, $16 \%$ of HCWs had not been immunized against $\mathrm{HBV}$, although they were in danger of blood and body fluids exposures. In Brazil, $44 \%$ of dentists after sharp injury and $14 \%$ of them after mucosal contamination with potentially infectious fluids investigated whether the source patient was carrier of bloodborne viruses or not, and only $11 \%$ of them sought medical aid after occupational exposure. [8]

Recently, there's an increasing attention towards occupational hazards in HCWs and so as to reduce the hazards, several protocols and guidelines are established in developed countries. However, to the best of our knowledge, there's no precise information on the dentists' behavior after blood and body fluids exposure in Iran. To enhance the HCWs safety and establish local guidelines, more information is important. Previously our team has a rich experience in working on various research projects across multiple disciplines The [9-23]. The Aim of the study is to assess the knowledge, attitude, and practice of dentists working in saveetha dental dental college regarding prophylaxis after exposure to blood and body fluids.

\section{Materials And Methods}

This was a cross-sectional study conducted among dental students undergoing training in saveetha dental college and hospitals. Data were collected by means of a self-administered questionnaire consisting of 10 closed ended questions. The survey was prepared in the form of google forms and was sent to potential responders.
100 people have responded to the survey. The questionnaire consisted of questions regarding knowledge about prophylaxis after exposure to blood and body fluids Convenient sampling method was used for data collection. The responses were presented as percentages. Data was tabulated and statistical analysis was done using spss software.

\section{Results And Discussion}

From the results [fig1] $96 \%$ of the students said they evaluate general health and medical history before dental care. [fig2] When asked if they wear protective equipment while treating patient $92 \%$ of the participants wear protective gear while treating patients. [fig3] 79\% of the students were aware of the PEP whereas $21 \%$ of the students aren't aware of the PEP. [fig 4] $72 \%$ of the study participants know when PEP is indicated whereas the other $28 \%$ of the participants do not know about it. [fig 7] $36 \%$ of the study population does not know the preferable time to take PEP. however [fig 9$] 70 \%$ of the participants know the duration to which PEP to be taken and $30 \%$ of the participants doesn't know the duration of the pep to be taken. [fig 5] 59\% of the participants know the guidelines for taking pep whereas other $41 \%$ do not know about it.[fig 6] 97\% of the participants agree with the fact that PEP reduces the likelihood of being HIV positive. [fig 8] when asked regarding maximum delay for taking PEP majority of the participants responded as 72 hours. [fig 10] $68 \%$ of the participants did not attend any training regarding post exposure prophylaxis whereas $32 \%$ have attended.

HIV and HBV constitute a serious public health concern, and occupational exposure of HCWs to these viruses poses a threat to healthcare delivery systems in resource-limited settings. Standard precautions have been advocated by the Centre for Disease Control (CDC, USA) as a means to reduce occupational exposures

Figure 1. Bar graph represents the distribution of responses between male and female. $\mathrm{X}$ axis represents gender and $\mathrm{Y}$ axis represents no of responses. When asked "Do you evaluate your patients general health and past medical history before dental care" 96 have responded yes and 4 have responded no. Pearson chi square test was done and it gave a $\mathrm{p}$ value was 0.614 which is $>0.05$ hence the results were not statistically significant implying no association between the gender and responses.

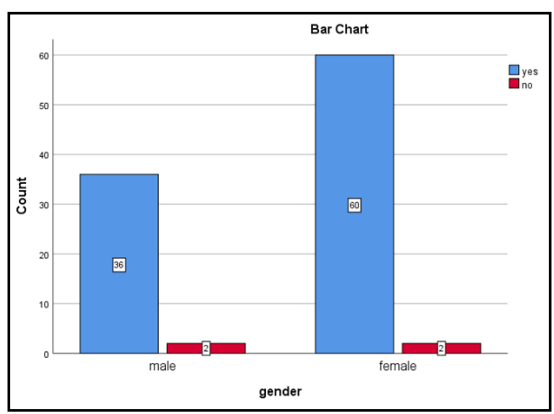

Figure 2. Bar graph represents the distribution of responses between male and female. $\mathrm{X}$ axis represents gender and $\mathrm{Y}$ axis represents no of responses. When asked Do you wear protective wear while treating patient's" 92 have responded yes and 8 have responded no. Pearson chi square test was done and it gave a $\mathrm{p}$ value was 0.976 which is $>0.05$ hence the results were not statistically significant implying no association between the gender and responses.

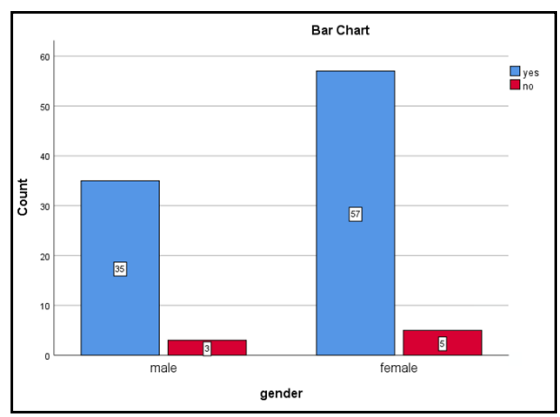


Figure 3. Bar graph represents the distribution of responses between male and female. $\mathrm{X}$ axis represents gender and $\mathrm{Y}$ axis represents no of responses. When asked "Do you know what is PEP" 79 have responded yes and 21 have responded no. Pearson chi square test was done and it gave a palue was 0.992 which is $>0.05$ hence the results were not statistically significant implying no association between gender and responses.

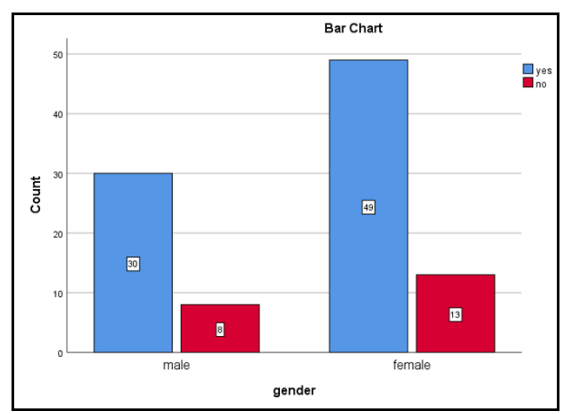

Figure 4. Bar graph represents the distribution of responses between male and female. $\mathrm{X}$ axis represents gender and $\mathrm{Y}$ axis represents no of responses. When asked "When do you think PEP should be indicated" 71 have responded to needle stick injury at work place 19 have responded when patient is hiv positive and 9 have responded when patient is at risk of hiv. Pearson chi square test was done and it gave a value was 0.343 which is $>0.05$ hence the results were not statistically significant implying no association between gender and responses.

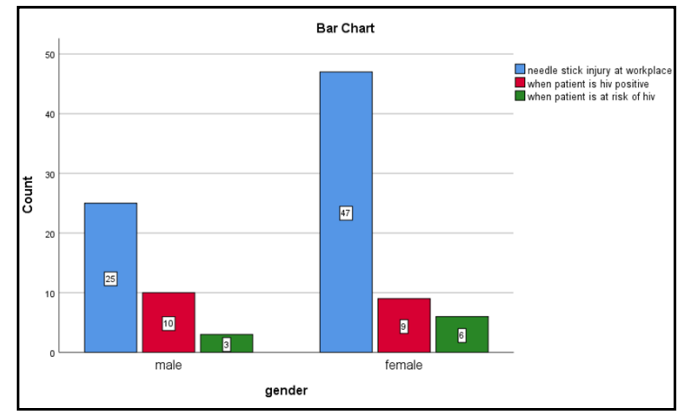

Figure 5. Bar graph represents the distribution of responses between male and female. $\mathrm{X}$ axis represents gender and $\mathrm{Y}$ axis represents no of responses. When asked "Do you know about the PEP guidelines" 59 have responded yes and 41 have responded no. Pearson chi square test was done and it gave a p value was 0.860 which is $>0.05$ hence the results were not statistically significant implying no association between gender and responses.

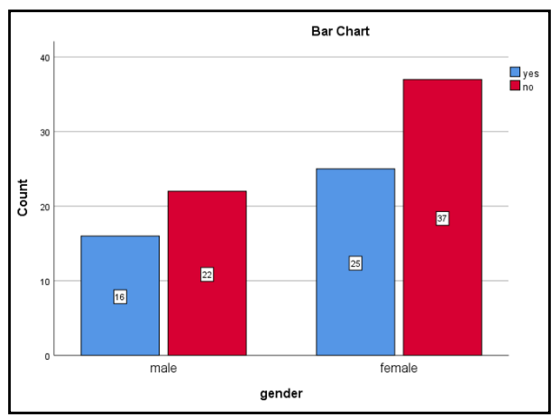

Figure 6. Bar graph represents the distribution of responses between male and female. $\mathrm{X}$ axis represents gender and $\mathrm{Y}$ axis represents no of responses. When asked Do you think PEP reduces the likelihood of being HIV positive" 96 have responded yes and 4 have responded no. Pearson chi square test was done and it gave a p value was 0.614 which is $>0.05$ hence the results were not statistically significantimplying no association between gender and responses.

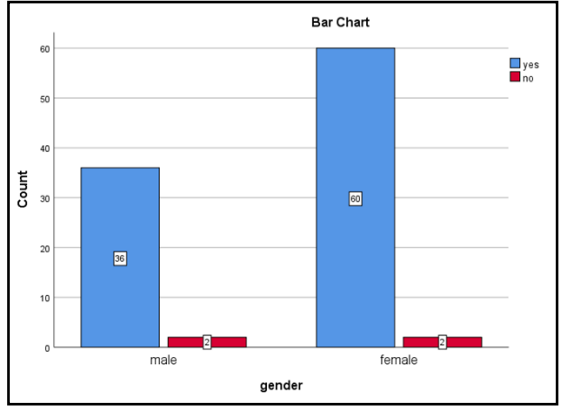

to HIV and other blood-borne pathogens. [24] In spite of the precautions, occupational exposure still occurs. Therefore, studies relating to knowledge, attitude and practices of HCWs are vital as they help to inform policy formulations on occupational PEPs against blood-borne pathogens, such as HIV and HBV.

This study shows that $77 \%$ of the participants have heard about PEP for HIV. This finding is higher than similar studies conduct- ed in India. In the institution where the present study was done, there is an infection control unit where incidences of occupational exposures are reported and PEP Instituted. But, updates or seminars on standard precautions and PEP aren't routinely finished the HCWs.

In this study, $73 \%$ of respondents had knowledge of the best time for the initiation of PEP, which is higher compared to that 
Figure 7. Bar graph represents the distribution of responses between male and female. $\mathrm{X}$ axis represents gender and $\mathrm{Y}$ axis represents no of responses. When asked preferable time for taking PEP. majority of the participants said "within an hour" followed by "after 6 hours" Chi square test to determine the association of response with gender gave a $\mathrm{p}$ value of 0.718 which was $>0.05$ hence the results were not statistically significant implying no association between gender and responses.

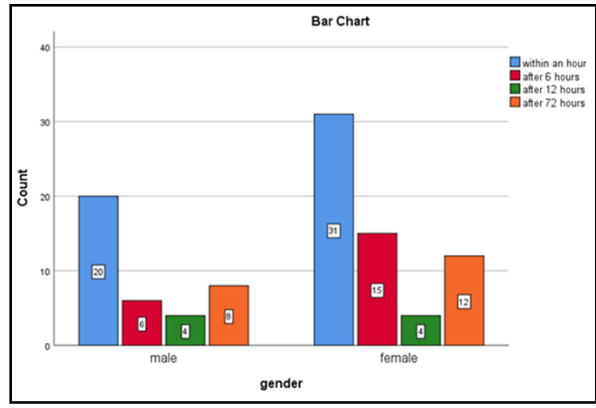

Figure 8. Bar graph represents the distribution of responses between male and female. $\mathrm{X}$ axis represents gender and $\mathrm{Y}$ axis represents no of responses. When asked maximum delay for taking PEP. majority of the participants said " 72 hours" followed by " 24 hours" chi square test to determine the association of response with gender gave a $\mathrm{p}$ value of 0.556 which was $>0.05$ hence the results were not statistically significant implying no association between gender and responses.

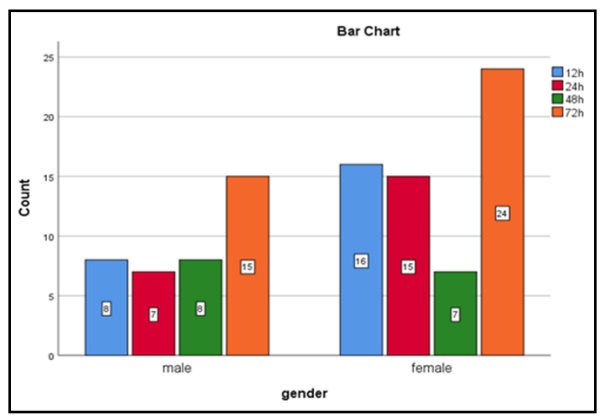

Figure 9. Bar graph represents the distribution of responses between male and female. $\mathrm{X}$ axis represents gender and $\mathrm{Y}$ axis represents no of responses. When asked "duration fo which PEP to be taken". majority of the participants said " 6 months" followed by " 28 days" chi square test to determine the association of response with gender gave a $\mathrm{p}$ value of 0.416 which was $>0.05$ hence the results were not statistically significant implying no association between gender and responses.

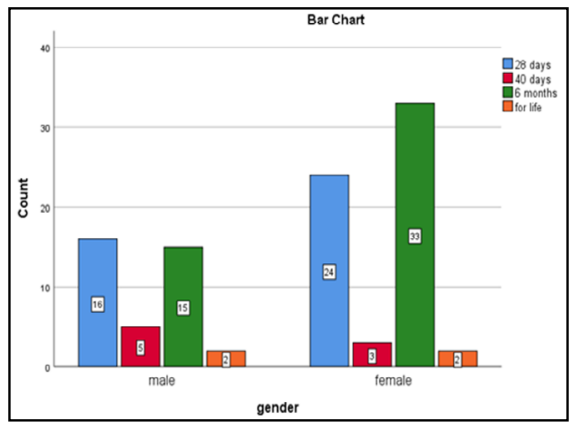

Figure 10. Bar graph represents the distribution of responses between male and female. $\mathrm{X}$ axis represents gender and $\mathrm{Y}$ axis represents no of responses. When asked did you attend a course on post exposure prophylaxis" $68 \%$ of the participants said 'no' and $32 \%$ of the participants said yes chi square test to determine the association of response with gender gave a p value of 0.351 which was $>0.05$ hence the results were not statistically significant implying no association between gender and responses.

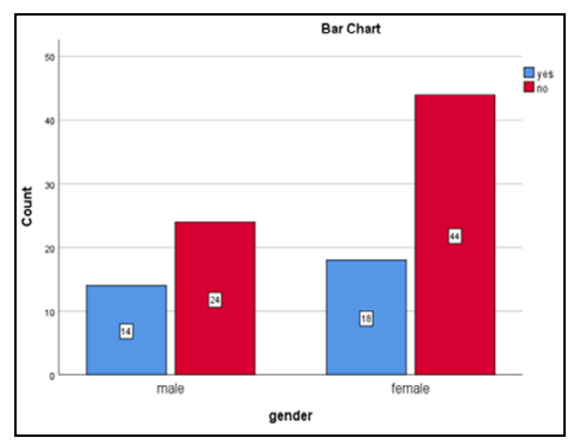

reported by Mathewos et al., among HCWs, [25] Kasat et al., [26] among postgraduate dental surgeons. The difference might be due to the difference on the level of awareness among the different study populations. The maximum benefit of PEP is obtained by commencing prophylaxis within the first hour of exposure, although it may be delayed to a maximum of 72 hours, after which it is less effective in preventing infection. The present study shows that $70 \%$ knew the length of time to take PEP. This value is low compared to previous reports from Nigeria [27] but higher than the report from a study among HCWs in Indian. [28] This study shows that only $28 \%$ of the participants have attended any training about PEP. This may be due to the fact that training or semi- 
nars on PEP and standard precautions aren't frequently administered for the HCWs within the institution. This is less than the Mathewos et al. [25], but higher than the report by Shivaprakash et al.,[28] among dental surgeons in India. The majority of the dental surgeons in the present study had adequate knowledge about PEP for blood-borne viral infections, which is higher than the finding of Tebeje and Hailu [29] in south-west Ethiopia, but slightly higher than what is reported in a Zimbabwean study [30]. The dental surgeons exhibited a good attitude towards PEP for $\mathrm{HIV} / \mathrm{HBV}$. Over $95 \%$ of the participants agreed on the importance of PEP for HIV/HBV and the availability of PEP guidelines in work place. This finding was similar to that reported by Mathewos et al.,[25].

The available medical literature does not adequately address the issue of the HCW's knowledge-base on modes of transmission and PEP for HBV and HCV. [31] Some of the reasons cited by the respondentsin study by sivaprakash et al for not taking of the PEP service included: fear of stigmatisation and discrimination; lack of awareness of the existence of the PEP service and protocol; and, lack of understanding of the value of reporting exposures. Comparatively, an alarmingly high proportion of $\mathrm{Ni}$ gerian surgeons in another centre took no action once they were exposed. [32] A study of European medical students found that few students did not report needlestick injuries, [33] and only 18\% of London, England, doctors sought advice regarding PEP despite over three-quarters of doctor reporting occupational injury. [7] the rationale for the discontinuation of PEP was found to be fear of adverse effects among the respondents. This finding was in agreement with another study conducted in Dar es Salaam, in which they showed that many respondents failed to use PEP for the full length of the time prescribed [34]. Our institution is passionate about high quality evidence based research and has excelled in various fields [35-45]. One of the limitations of our study was that in evaluating the dentists' practice, we trusted their personal statements, which might be different from their real practice. Moreover, this research was a cross sectional study and thus suffered from all limitations of this type of the study.

\section{Conclusion}

In conclusion, the study revealed that the knowledge and practice of dental surgeons prophylaxis after exposure to blood and body fluids is Availability of a formal PEP training centre with proper guidelines is recommended to enhance the knowledge attitude and practice amongst dental surgeons regarding prophylaxis after exposure to blood and body fluids.

\section{Acknowledgement}

With sincere gratitude, we acknowledge the staff members of the department of oral and maxillofacial surgery, department of conservative dentistry and endodontics and saveetha dental college and study participants for their extended support towards the completion of research.

\section{Authors Contribution}

Abhishek - carried out the survey and writing of the manuscript Dr. Balakrishnan- corresponding author and guided the study Dr.Deepak - review of the article.

\section{References}

[1]. Alter MJ, Alvarado-Ramy F, Beltrami EM, Bower WA, Cardo DM, Critchley SE, et al. Updated US Public Health Service guidelines for the management of occupational exposures to HBV, HCV, and HIV and recommendations for postexposure prophylaxis.2001.

[2]. APPENDIX B. Management of Occupational Blood Exposures 2001.

[3]. Cardo DM, Culver DH, Ciesielski CA, Srivastava PU, Marcus R, Abiteboul $\mathrm{D}$, et al. A case-control study of HIV seroconversion in health care workers after percutaneous exposure. N Engl J Med. 1997 Nov 20;337(21):1485-90.

[4]. Shimoji S, Ishihama K, Yamada H, Okayama M, Yasuda K, Shibutani T, et al. Occupational safety among dental health-care workers. Adv Med Educ Pract. 2010;1:41-7.

[5]. Ishihama K, Iida S, Koizumi H, Wada T, Adachi T, Isomura-Tanaka E, et al. High incidence of blood exposure due to imperceptible contaminated splatters during oral surgery. J Oral Maxillofac Surg. 2008 Apr;66(4):704-10. Pubmed PMID: 18355594.

[6]. Askarian M, Malekmakan L, Memish ZA, Assadian O. Prevalence of needle stick injuries among dental, nursing and midwifery students in Shiraz, Iran. GMS Krankenhhyg Interdiszip. 2012;7(1).

[7]. Chen MY, Fox EF, Rogers CA. Post-exposure prophylaxis for human immunodeficiency virus: knowledge and experience of junior doctors. Sex Transm Infect. 2001 Dec;77(6):444-5. Pubmed PMID: 11714945.

[8]. Garcia LP, Blank VL. Management of occupational exposures to potentially infectious materials in dentistry. Rev Saude Publica. 2008 Apr;42(2):279-86.

[9]. Hafeez N. Accessory foramen in the middle cranial fossa. Res J Pharm Technol. 2016 Nov 1;9(11):1880.

[10]. Krishnan RP, Ramani P, Sherlin HJ, Sukumaran G, Ramasubramanian A, Jayaraj G, et al. Surgical Specimen Handover from Operation Theater to Laboratory: A Survey. Ann Maxillofac Surg. 2018 Jul-Dec;8(2):234-238. Pubmed PMID: 30693238.

[11]. Somasundaram S, Ravi K, Rajapandian K, Gurunathan D. Fluoride Content of Bottled Drinking Water in Chennai, Tamilnadu. J Clin Diagn Res. 2015 Oct;9(10):ZC32-4.Pubmed PMID: 26557612.

[12]. Felicita AS. Orthodontic extrusion of Ellis Class VIII fracture of maxillary lateral incisor - The sling shot method. Saudi Dent J. 2018 Jul;30(3):265269.Pubmed PMID: 29942113.

[13]. Kumar S, Rahman RE. Knowledge, awareness, and practices regarding biomedical waste management among undergraduate dental students Asian J Pharm Clin Res. 2017;10(8):341.

[14]. Gurunathan D, Shanmugaavel AK. Dental neglect among children in Chennai. J Indian Soc Pedod Prev Dent. 2016 Oct 1;34(4):364.

[15]. Sneha S. Knowledge and awareness regarding antibiotic prophylaxis for infective endocarditis among undergraduate dental students. Asian J Pharm Clin Res. 2016 Oct 1:154-9.

[16]. Dhinesh B, Lalvani JI, Parthasarathy M, Annamalai K. An assessment on performance, emission and combustion characteristics of single cylinder diesel engine powered by Cymbopogon flexuosus biofuel. Energy Convers Manage. 2016 Jun 1;117:466-74.

[17]. Choudhari S, Thenmozhi MS. Occurrence and Importance of Posterior Condylar Foramen. LATERALITY. 2016 Aug 28;8:11-43.

[18]. Paramasivam A, Vijayashree Priyadharsini J, Raghunandhakumar S. N6adenosine methylation (m6A): a promising new molecular target in hypertension and cardiovascular diseases. Hypertens Res. 2020 Feb;43(2):153154.Pubmed PMID: 31578458.

[19]. Wu F, Zhu J, Li G, Wang J, Veeraraghavan VP, Krishna Mohan S, et al. Biologically synthesized green gold nanoparticles from Siberian ginseng induce growth-inhibitory effect on melanoma cells (B16). Artif Cells Nanomed Biotechnol. 2019 Dec;47(1):3297-3305.Pubmed PMID: 31379212.

[20]. Palati S, Ramani P, Shrelin HJ, Sukumaran G, Ramasubramanian A, Don $\mathrm{KR}$, et al. Knowledge, Attitude and practice survey on the perspective of oral lesions and dental health in geriatric patients residing in old age homes. Indian J Dent Res. 2020 Jan-Feb;31(1):22-25.Pubmed PMID: 32246676.

[21]. Saravanan M, Arokiyaraj S, Lakshmi T, Pugazhendhi A. Synthesis of silver nanoparticles from Phenerochaete chrysosporium (MTCC-787) and their antibacterial activity against human pathogenic bacteria. Microb Pathog. 2018 Apr;117:68-72.Pubmed PMID: 29427709.

[22]. Govindaraju L, Gurunathan D. Effectiveness of Chewable Tooth Brush in Children-A Prospective Clinical Study. J Clin Diagn Res. 2017 Mar;11(3):ZC31-ZC34.Pubmed PMID: 28511505.

[23]. Vijayakumar Jain S, Muthusekhar MR, Baig MF, Senthilnathan P, Loganathan S, Abdul Wahab PU, et al. Evaluation of Three-Dimensional Changes in Pharyngeal Airway Following Isolated Lefort One Osteotomy for the Correction of Vertical Maxillary Excess: A Prospective Study. J Maxillofac Oral Surg. 2019 Mar;18(1):139-146.Pubmed PMID: 30728705. 
[24]. CDC A. Perspectives in Disease Prevention and Health Promotion Update: Universal Precautions for Prevention of Transmission of Human Immunodeficiency Virus, Hepatitis B Virus, and Other Bloodborne Pathogens in Health-Care Settings. MMWR Surveill Summ:1988;37 (24): 377-388.

[25]. Mathewos B, Birhan W, Kinfe S, Boru M, Tiruneh G, Addis Z, et al. Assessment of knowledge, attitude and practice towards post exposure prophylaxis for HIV among health care workers in Gondar, North West Ethiopia. BMC Public Health. 2013 May 25;13:508.Pubmed PMID: 23705668.

[26]. Kasat V, Saluja H, Ladda R, Sachdeva S, Somasundaram K, Gupta A. Knowledge, Attitude and Practices toward Post Exposure Prophylaxis for Human Immunodeficiency Virus among Dental Students in India. Ann Med Health Sci Res. 2014 Jul;4(4):543-8.Pubmed PMID: 25221701.

[27]. Agaba PA, Agaba EI, Ocheke AN, Daniyam CA, Akanbi MO, Okeke EN. Awareness and knowledge of human immunodeficiency virus post exposure prophylaxis among Nigerian Family Physicians. Niger Med J. 2012 Jul;53(3):155-60.Pubmed PMID: 23293417.

[28]. Shivaprakash G, Punya S, Pallavi LC. Assessment of knowledge of post exposure prophylaxis (PEP) for HIV among healthcare workers (HCWS) at a tertiary care hospital. World J Pharm Sci. 2015;4(3):1091-9.

[29]. Tebeje B, Hailu C. Assessment of HIV Post-Exposure Prophylaxis Use Among Health Workers of Governmental Health Institutions in Jimma Zone, Oromiya Region, Southwest Ethiopia. Ethiop J Health Sci. 2010 Mar;20(1):55-64.Pubmed PMID: 22434961.

[30]. Monera T, Ncube P. Assessment of knowledge, attitude and practice of health care workers on occupational HIV post exposure prophylaxis at Zimbabwean referral hospital. J Int AIDS Soc. 2012;15(4):523-30.

[31]. Baheti AD, Tullu MS, Lahiri KR. Awareness of health care workers regarding prophylaxis for prevention of transmission of blood-borne viral infections in occupational exposures. Al Ameen J Med Sci. 2010;3(1):79-83.

[32]. Nwankwo TO, Aniebue UU. Percutaneous injuries and accidental blood exposure in surgical residents: awareness and use of prophylaxis in relation to HIV. Niger J Clin Pract. 2011 Jan-Mar;14(1):34-7.Pubmed PMID: 21493989

[33]. Salzer HJ, Hoenigl M, Kessler HH, Stigler FL, Raggam RB, Rippel KE, et al. Lack of risk-awareness and reporting behavior towards HIV infection through needlestick injury among European medical students. Int J Hyg Environ Health. 2011 Sep;214(5):407-10.Pubmed PMID: 21665538.

[34]. Chagani MM, Manji KP, Manji MP, Sheriff FG. Healthcare workers' knowledge, attitudes, practices on post exposure prophylaxis for HIV in Dar es Salaam. Tanzan. Med. J. 2011;25(2):33-8.

[35]. Vijayashree Priyadharsini J. In silico validation of the non-antibiotic drugs acetaminophen and ibuprofen as antibacterial agents against red complex pathogens. J Periodontol. 2019 Dec;90(12):1441-1448.Pubmed PMID: 31257588.

[36]. PC J, Marimuthu T, Devadoss P, Kumar SM. Prevalence and measurement of anterior loop of the mandibular canal using CBCT: A cross sectional study. Clin Implant Dent Relat Res. 2018 Apr 6;20(4):531-4.

[37]. Ramesh A, Varghese S, Jayakumar ND, Malaiappan S. Comparative estimation of sulfiredoxin levels between chronic periodontitis and healthy patients - A case-control study. J Periodontol. 2018 Oct;89(10):1241-1248.Pubmed PMID: 30044495.

[38]. Ramadurai N, Gurunathan D, Samuel AV, Subramanian E, Rodrigues SJ. Effectiveness of $2 \%$ Articaine as an anesthetic agent in children: randomized controlled trial. Clin Oral Investig. 2019 Sep;23(9):3543-50.

[39]. Sridharan G, Ramani P, Patankar S, Vijayaraghavan R. Evaluation of salivary metabolomics in oral leukoplakia and oral squamous cell carcinoma. J. Oral Pathol. Med. 2019 Apr;48(4):299-306.

[40]. Ezhilarasan D, Apoorva VS, Ashok Vardhan N. Syzygium cumini extract induced reactive oxygen species-mediated apoptosis in human oral squamous carcinoma cells. J Oral Pathol Med. 2019 Feb;48(2):115-121.Pubmed PMID: 30451321.

[41]. Mathew MG, Samuel SR, Soni AJ, Roopa KB. Evaluation of adhesion of Streptococcus mutans, plaque accumulation on zirconia and stainless steel crowns, and surrounding gingival inflammation in primary molars: randomized controlled trial. Clin Oral Investig. 2020 Sep;24(9):1-6.Pubmed PMID: 31955271

[42]. Samuel SR. Can 5-year-olds sensibly self-report the impact of developmental enamel defects on their quality of life? Int J Paediatr Dent. 2021 Mar;31(2):285-286.Pubmed PMID: 32416620

[43]. R H, Ramani P, Ramanathan A, R JM, S G, Ramasubramanian A, et al. CYP2 C9 polymorphism among patients with oral squamous cell carcinoma and its role in altering the metabolism of benzo[a]pyrene. Oral Surg Oral Med Oral Pathol Oral Radiol. 2020 Sep;130(3):306-312.Pubmed PMID: 32773350 .

[44]. Chandrasekar R, Chandrasekhar S, Sundari KKS, Ravi P. Development and validation of a formula for objective assessment of cervical vertebral bone age. Prog Orthod. 2020 Oct 12;21(1):38.Pubmed PMID: 33043408.

[45]. Vijayashree Priyadharsini J, Smiline Girija AS, Paramasivam A. In silico analysis of virulence genes in an emerging dental pathogen A. baumannii and related species. Arch Oral Biol. 2018 Oct;94:93-98.Pubmed PMID: 30015217. 